\title{
EVALUATION OF THE REGIONAL DIFFERENCES OF THE “GREEN” ECONOMY DEVELOPMENT IN UKRAINE
}

\author{
'Olena KONONENKO, ${ }^{2}$ Serhii SVYNARETS \\ Taras Shevchenko National University of Kyiv, Ukraine \\ 2lyotya@gmail.com
}

\begin{abstract}
The article deals with the main methodological approaches which are used in the world's practice for the researches of "green" economy. The problem of applicating statistics information for the assessment of "green" economy development level is investigated. Stimulating and disincentive factors of the "green" economy development are defined. The authors offer a methodological approach which enables to evaluate the development level of the "green" economy in the region in virtue of statistics information evaluation. This approach is tested on the example of Ukrainian regions. The main reasons leading to prominent disproportions in the level of development are revealed.
\end{abstract}

Key words: "green" economy, sustainable development, regional differences, integrated index, indicators of development

UDC: $911.3: 504.03$

\section{ОЦІНКА РЕГІОНАЛЬНИХ ВІДМІННОСТЕЙ ФОРМУВАННЯ «ЗЕЛЕНОЇ» ЕКОНОМІКИ В УКРАЇНІ}

\author{
'Олена КОНОНЕНКО, ²Сергій СВИНАРЕЦЬ \\ Київський начіональний університет імені Тараса Шевченка, Україна \\ 2lyotya@gmail.com
}

\begin{abstract}
Анотація: У статті розглянуто основні методичні підходи, що використовуються у світовій практиці для дослідження «зеленої» економіки. Досліджено проблему використання статистичної інформації для оцінки рівня розвитку «зеленої» економіки. Визначені фактори стимулятори та дестимулятори сталого розвитку. Запропоновано методичний підхід, який дозволяє на основі аналізу статистичної інформації оцінити рівень розвитку «зеленої» економіки в регіоні. Проведено його апробацію на прикладі регіонів України. Наведені основні причини, що спричинили формування значних диспропорцій у рівні розвитку.

Ключові слова: «зелена» економіка, сталий розвиток, регіональні відмінності, інтегральний індекс, індикатори розвитку
\end{abstract}

Удк: 911.3:504.03

Вступ. Постановка проблеми. Одними із найбільших проблем сучасності $\epsilon$ нераціональне використання природних ресурсів, зміна клімату, бідність, перенаселення окремих регіонів планети тощо. Дані проблеми негативно впливають на соціально-економічний розвиток територій, і тому, експертами ООН були надані рекомендації щодо використання моделі «зеленої» економіки, що дасть змогу досягнути основної мети людства цього тисячоліття - сталого розвитку суспільства.

В сучасних соціально-економічних умовах Україна потребує кардинальних змін та заміни неефективної моделі управління господарством. На нашу думку, одним із пріоритетних напрямків економічних реформ в нашій країні повинні бути реформи «озеленення» господарства, що в довгостроковій перспективі допоможе зменшити витрати ресурсів та фінансів, залучити нові інвестиції та наблизитися до сталого суспільного розвитку. Для України характерна значна територіальна поляризація економічного розвитку i тому, деякі регіони вже сьогодні починають використовувати переваги «зеленого» курсу. Водночас, в офіційній статистиці не існує єдиного

(C) О. Кононенко, С. Свинарець показника, що може відображати реальну картину територіальної диференціації розвитку «зеленої» економіки, що зміг би значно полегшити прийняття управлінських рішень щодо планування територіально розвитку, розподілу інвестицій та ведення регіональної соціальної та економічної політики.

Аналіз останніх досліджень та публікацій. Станом на сьогодні існує велика кількість наукових праць вітчизняних та зарубіжних вчених, що стосуються проблематики «зеленої» економіки та досягнення сталого розвитку суспільства та навколишнього середовища. До основоположників концепції стійкого розвитку в світі слід віднести М. Джейкобса [8], Донеллу та Деніса Медоузів [10], які представляють різні галузі науки: економіку, екологію, кібернетику тощо. Провідним світовим центром дослідження проблем «зеленої» економіки $\epsilon$ Green Economics Institute, який був заснований у 2004 році у місті Редінг (Великобританія), одним із фундаторів сучасного бачення «зеленої» економіки Маріам Кеннет [9]. Даний інститут регулярно видає International Journal of Green Economics, що є одним iз провідним вісників у галузі «зеленої» економіки та сталого розвитку. Дякуючи своїй новизні та актуальності поставлених питань, «зелена» економіка 
стала однією із основних тем дослідження таких суспільних інституцій та наукових організацій як ЮНЕП (Програма ООН з навколишнього середовща) [5; 11], Всесвітній Інститут Спостереження [16], Свропейська Агенція з Навколишнього Середовища [4], Інститут для глобальних змін навколишнього середовища [6] тощо.

В Україні проблемою впровадження «зеленої» економіки займались такі вчені як Б. Буркинський [1], Т. Галушкіна [1], В. Потапенко [12], В. Реутов [1], М. Хвесик [7], О. Чмир [2], що в основному приділяли увагу екологізації господарства країни та налагодженню раціонального природокористування, розробці стратегії та механізмів сталого розвитку для України. Локальний та регіональний рівень розвитку «зеленої» економіки майже не досліджений через низький рівень їі розвитку та брак статистичної інформації. Але актуальність теми та загальносвітові тенденції вимагають проведення подібних досліджень для обгрунтування наукових засад формування i розвитку «зеленої» економіки в Україні.

Формування цілей статті, постановка завдання. Обгрунтувати необхідність обчислення статистичних показників-індикаторів розвитку «зеленої» економіки для регіонів країни та запропонувати власну методику обрахування інтегрального показника розвитку «зеленої» економіки.

Виклад основного матеріалу. Починаючи iз 90-х років XX століття світове суспільство почало активно обговорювати необхідність трансформації економічної моделі на таку, що б дозволила збільшити ресурсоефективість виробництва та забезпечити сталий розвиток суспільства та навколишнього середовища [11]. Першими міжнародними конференціями, що поклали основу поширенню ідей стійкого розвитку, які здатні вирішити встановлені ООН загрози нового тисячоріччя, стали Конференція у Ріо-де-Жанейро 1992 року та Конференція у Йоханнесбурзі у 2002 році. Після світової фінансової кризи 2008 року «зелена» економіка почала сприйматися як ефективна альтернатива наявній економічній системі, що забезпечить сталість та стабільність суспільного розвитку. Багато країн почали запроваджувати певні аспекти вже вище згаданої політики, і не стала виключенням й Україна: необхідність переходу до «зеленої» економічної моделі були зазначені у Державній програмі внутрішнього виробництва до 2015 р. та Законі України «Про основні засади (стратегію) державної екологічної політики України на період до 2020 року» від 21 лютого 2010 року [17].

Проте, не зважаючи на досить добре розроблене законодавство України щодо сприяння розвитку «зеленого» бізнесу, фактичний стан справ у даній галузі $\epsilon$ досить далеким від задовільного. Варто зазначити, що через низку об'єктивних та суб'єктивних причин розвиток «зеленого» господарства є неоднорідним на території держави, i тому, при плануванні подальшого розвитку території, а також плануванні видатків бюджету на розвиток сталого господарства потрібно спиратися на низку статистичних показників, що зможуть проілюструвати територіальну диференціацію у розвитку «зеленої» економіки. Без розробленої системи індексів та показників, універсальних засобів обліку, які були би зрозумілі як в економічному так i в екологічному сенсах, не можливо забезпечити функціонування «зеленої» економіки [3].

У світовій практиці використовуються різні підходи для оцінки рівня розвитку «зеленої» економіки території. Так, наприклад, для розрахунку Індексу зелених міст, який щорічно проводить Economist Intelligence Unit (The Economist Group), зараховуються статистичні показники із наступних категорій: енергетика, законодавство щодо навколишнього середовища, викиди $\mathrm{CO}_{2}$, будівництво, транспорт, відходи та використання землі, вода та якість повітря [15]. Для оцінки рівня сталості економік країн ЄC European Environmental Agency використовує показники, що відображають сучасний стан економіки, екосистем та людського добробуту, але найбільша увага при аналізі «зеленої» економіки дана агенція приділяє таким блокам питань, як виробництво та споживання їжі, використання води, виробництво і споживання електроенергії, будівництво [4]. ЮНЕП вважає, що одними із головних задач сучасного розвитку $є$ «озеленення» сільського господарства, відновлення природного капіталу, забезпечення населення питною водою та раціональне використання водних ресурсів, розвиток відновної енергетики та стимулювання поширення явища «зеленого» туризму [11]. Відповідно, дана організація поділяе країни світу за рівнем розвитку спираючись на рівень досягнення поставлених цілей.

Відбір статистичної інформації для проведення дослідження регіональних особливостей розвитку «зеленої» економіки проводився 3 урахуванням наступних вимог:

1) Наявність статистичної інформації для всіх адміністративно-територіальних одиниць України.

2) Достовірність наявних даних.

3) Використання даних, що знаходяться у відкритому доступі.

4) Охоплені дані повинні бути індикаторами якнайбільшої кількості секторів «зеленої» економіки.

Для вихідної бази даних були проаналізовані видання Державної служби статистики України та декілька інтернет-ресурсів [13; 14]. Отже, враховуючи викладені вище обмеження, перелік показників, що використовувались у доданому дослідженні, $є$ наступним:

частка утилізованих та оброблених (перероблених) відходів від загальної кількості відходів I-IV класів небезпеки, що продукуються у регіоні.

- часта повторно використаної води у відношенні до загальної кількості води, що використовується у промисловості.

- кількість викидів забруднюючих речовин в 
Розвиток «зеленої» економіки у регіонах України у 2013 р. Обраховано за даними [13; 14].

\begin{tabular}{|c|c|c|c|c|c|c|c|}
\hline Регіон & 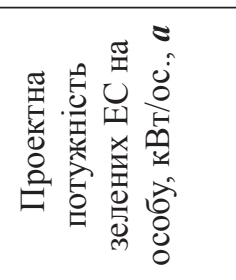 & 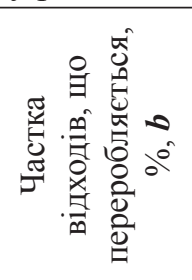 & 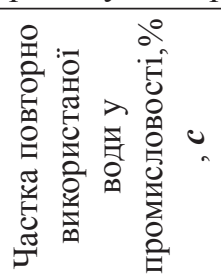 & 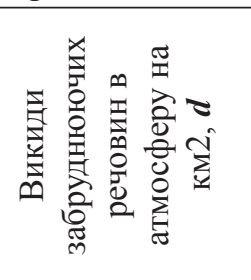 & 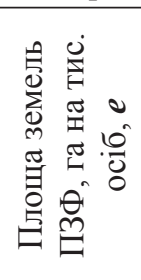 & 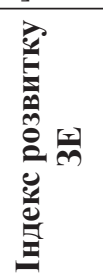 & 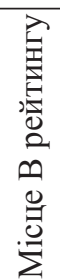 \\
\hline APK & 0,143 & 16 & 72 & 5 & 27,16 & 0,368 & 9 \\
\hline Вінницька & 0,051 & 8 & 95 & 8,6 & 12,48 & 0,311 & 17 \\
\hline Волинська & 0,000 & 14 & 57 & 2,4 & 87,68 & 0,399 & 6 \\
\hline Дніпропетровська & 0,012 & 34 & 84 & 35,9 & 1,15 & 0,209 & 24 \\
\hline Донецька & 0,022 & 21 & 88 & 62,1 & 14,85 & 0,226 & 23 \\
\hline Житомирська & 0,013 & 13 & 83 & 3 & 40,4 & 0,393 & 7 \\
\hline Закарпатська & 0,044 & 5 & 73 & 5,4 & 116,4 & 0,356 & 11 \\
\hline Запорізька & 0,078 & 39 & 91 & 13 & 53,44 & 0,322 & 15 \\
\hline Івано-Франківська & 0,019 & 31 & 97 & 18,2 & 82,7 & 0,306 & 18 \\
\hline Київська & 0,017 & 16 & 48 & 9,9 & 0,98 & 0,171 & 25 \\
\hline Кіровоградська & 0,060 & 47 & 88 & 3 & 0 & 0,408 & 5 \\
\hline Луганська & 0,002 & 30 & 96 & 19,6 & 2,41 & 0,243 & 22 \\
\hline Львівська & 0,036 & 6 & 90 & 10,9 & 23,64 & 0,284 & 19 \\
\hline Миколаївська & 0,114 & 5 & 97 & 3,4 & 36,8 & 0,461 & 3 \\
\hline Одеська & 0,108 & 4 & 71 & 4,9 & 41,48 & 0,355 & 12 \\
\hline Полтавська & 0,001 & 74 & 97 & 6,1 & 21,05 & 0,315 & 16 \\
\hline Рівненська & 0,008 & 4 & 98 & 2,8 & 41,16 & 0,436 & 4 \\
\hline Сумська & 0,001 & 33 & 88 & 3,3 & 34,95 & 0,377 & 8 \\
\hline Тернопільська & 0,008 & 28 & 57 & 4,2 & 16,3 & 0,267 & 20 \\
\hline Харківська & 0,004 & 13 & 91 & 10,5 & 8,29 & 0,26 & 21 \\
\hline Херсонська & 0,366 & 21 & 60 & 2,6 & 198,32 & 0,675 & 1 \\
\hline Хмельницька & 0,026 & 44 & 99 & 3,9 & 199,92 & 0,491 & 2 \\
\hline Черкаська & 0,090 & 76 & 94 & 7,2 & 1,59 & 0,337 & 13 \\
\hline Чернівецька & 0,029 & 22 & 98 & 4,8 & 30,6 & 0,363 & 10 \\
\hline Чернігівська & 0,0002 & 35 & 58 & 2,9 & 38,15 & 0,334 & 14 \\
\hline
\end{tabular}

атмосферу перерахована на метр квадратний.

- сумарна потужність альтернативних електростанцій в регіоні на одну особу.

- площа земель природоохоронного фонду у перерахунку на тисячу осіб.

Дані показники дають змогу відстежити стан розвитку окремих секторів «зеленої» економіки за регіонами, але мають і окремі недоліки.

По-перше, досить важко на сучасному етапі проаналізувати ефективність «зеленого» електроенергетичного сектору, адже єдиний показник, що є наявним у широкому доступі - це проектна потужність електростанцій. Більше того, його неможливо знайти у статистичних збірниках i довідниках, a лише на інтернет сторінках девелоперів та у проектних документах кожної окремої електростанції. Проектна потужність визначає максимально можливу потужність певної електростанції у моменти пікового навантаження, обчислюється у Вт. Даний індикатор не відображає реальну кількість виробленої електроенергії через те, що пікове навантаження на більшості альтернативних електростанцій досягається лише за дуже сприятливих природних умов: великій кількості сонячної радіації для СЕС, великої швидкості вітру для $\mathrm{BEC}$, паводковий стан річки на малих ГЕС, повне завантаження паливом електростанцій на біопаливі тощо. Тому варто зазначити, що хоча даний показник не відображає реальну частку «зеленої» електроенергетики у виробництві, проте він дає змогу проаналізувати обсяг реалізованих робіт у даній сфері та перспективи для подальшого розвитку альтернативного виробництва електроенергії.

По-друге, в Україні зовсім не вираховуються дані ані про обсяги виробництва продукції «зеленого» сільського господарства, ані площі земель, що використовуються під його потреби. Україна спеціалізується на виробництві сільськогосподарської продукції та в кожному регіоні $\epsilon$ компанії АПК, що мають сертифікат відповідності 
продукції до стандартів екологічно чистого виробництва «Organic», проте не ведеться збір жодної статистичної інформації у даному секторі «зеленого» господарства, що унеможливлює його включення до загального списку індикаторів при виведенні інтегрального показника.

У таблиці 1 представлено вихідні статистичні дані щодо розвитку основних секторів «зеленої» економіки, також розрахований індекс розвитку «зеленої» економіки.

Методика розрахунку Індексу розвитку «зеленої» економіки, потребує також попереднього обрахунку коефіцієнтів розвитку секторальних показників. За табл. 1 секторальний показник для проектної потужності «зелених» електростанцій буде мати буквене вираження - «a», для частки відходів, що переробляються - «b», і так далі для наступних трьох показників згідно латинській абетці. Для показників стимуляторів розвитку «зеленої» економіки (a, $\boldsymbol{b}, \boldsymbol{c}$ та $\boldsymbol{e})$ методика розрахунку секторального коефіцієнта буде однаковою, так як максимальні значення показників відповідають найвищому рівню розвитку, то коефіцієнт секторального розвитку буде розраховуватися наступним чином (1):

$$
\mathrm{K}_{\mathrm{a}}=\mathrm{a}_{\mathrm{i}} / \mathrm{a}_{\max }
$$

де $\mathrm{Ka}$ - коефіцієнт секторального розвитку за показником $\boldsymbol{a}$;

$\mathrm{a}_{\mathrm{i}}$ - значення показника $\boldsymbol{a}$ для певного регіону;

$\mathrm{a}_{\max }$ - максимальне значення показника $\boldsymbol{a}$.

За аналогією із коефіцієнтом секторального розвитку за показником $\boldsymbol{a}$ вираховуються секторальні коефіцієнти для $\boldsymbol{b}, \boldsymbol{c}$ та $\boldsymbol{e}$. Виходячи із даної формули можливо зробити висновок, що чим більше значення показника, тим більше i значення коефіцієнта розвитку.

Коефіцієнт секторального розвитку для показника-дестимулятора $\boldsymbol{d}$ (викиди забруднюючих речовин в атмосферу на км²) підраховується іншим чином, адже у даному випадку мінімальні показники відповідають найсприятливішій ситуації для розвитку регіону. Тому секторальний коефіцієнт для показника-дестимулятора буде мати наступний вигляд (2):

$$
K_{d}=d_{\min } / d_{i}
$$

де $K a$ - коефіцієнт секторального розвитку за показником $\boldsymbol{a}$;

$a_{i}$ - значення показника $\boldsymbol{a}$ для певного регіону;

$a_{\text {max }}$ - максимальне значення показника $\boldsymbol{a}$.

За другою формулою можна зробити висновок, що чим менше значення показника $\boldsymbol{d}$, тим більше значення секторального коефіцієнта розвитку.

Безумовним є той факт, що для гармонійного та сталого розвитку суспільства, при використанні моделі «зеленої» економіки, потрібний одночасний розвиток всіх їі секторів. Проте в сучасних реаліях розвиток деяких із секторів $€$ більш економічно доцільним та має більший економічний та екологічний ефект. В першу чергу, до таких секторів слід віднести енергетичний, що впливає на економічну безпеку країни, а також показники ресурсоефективності виробництва та менеджменту відходів, які впливають на життєдіяльність

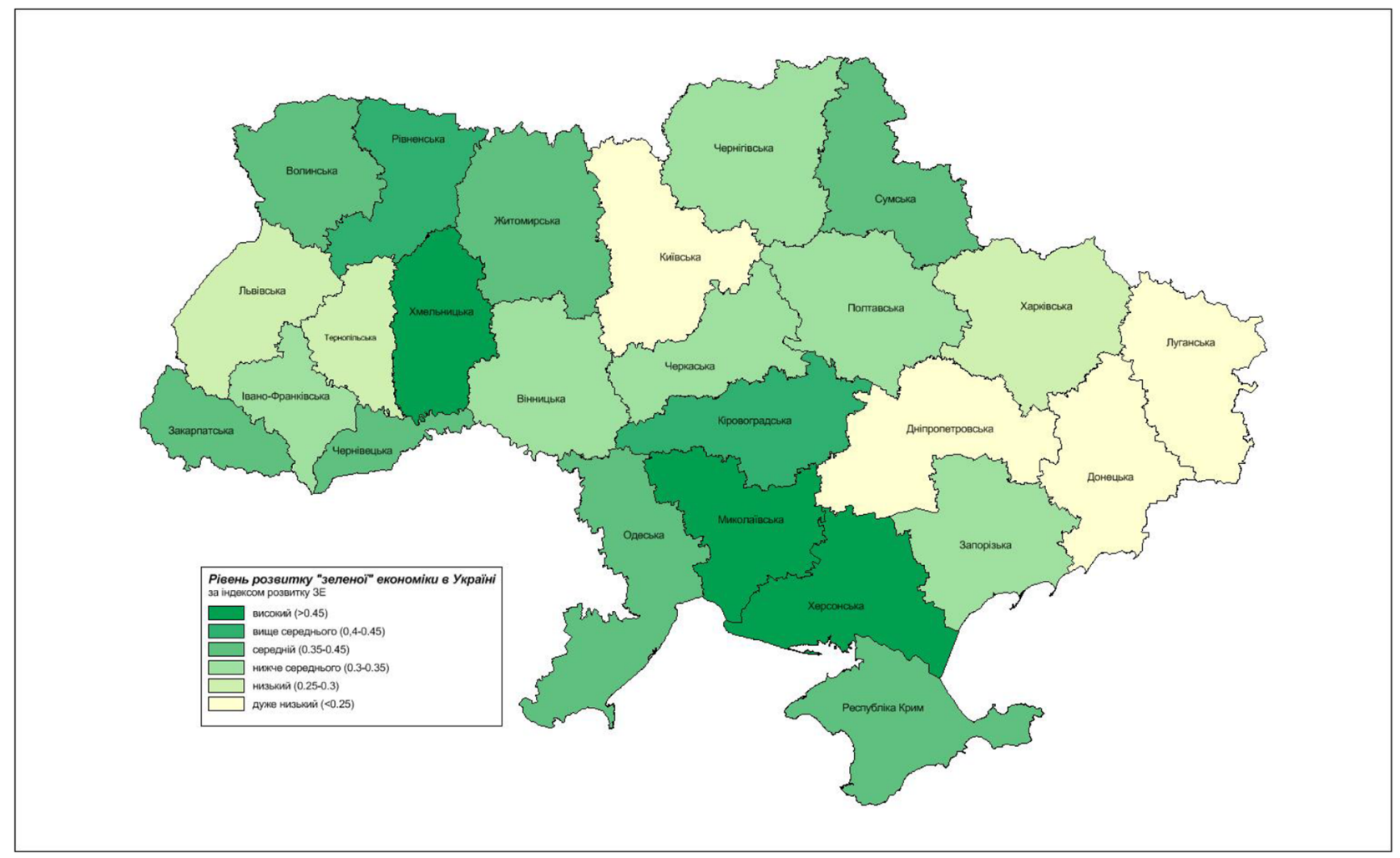

Рис. 1. Регіональні відміни у рівні розвитку «зеленої» економіки за інтегральним індексом, 2013. 
суспільства. Цим обумовлене надання секторальним коефіцієнтам різних вагових часток при підрахунку інтегрального індексу розвитку «зеленої» економіки: секторальним коефіцієнтам за показниками $\boldsymbol{a}, \boldsymbol{b}, \boldsymbol{c}$ та $\boldsymbol{d}$ варто надати більшу вагову частку у вигляді $22 \%$, а секторальному коефіцієнту за показником $\boldsymbol{e}-12 \%$. У сумі всі вагові частки дають 100 \%. І хоча показник «Площа земель ПЗФ»є важливим для ефективного екологічного та земельного менеджменту, його значимість у побудові нової моделі господарства $\epsilon$ меншою ніж у решти, більш інноваційних та сучасних галузей. Отже, формула розрахунку індексу розвитку «зеленої» економіки матиме наступний вигляд (3):

$$
\begin{aligned}
& I_{3 E}=0,22 K_{a}+0,22 K_{b}+0,22 K_{c}+0,22 K_{d}+ \\
& +0,12 K_{e}
\end{aligned}
$$

де $I_{3 E}-$ індекс розвитку «зеленої» економіки регіону;

$K_{a}, K_{b}, K_{c}, K_{d}, K_{e}$ - секторальні коефіцієнти розвитку регіону за показниками $\boldsymbol{a}, \boldsymbol{b}, \boldsymbol{c}, \boldsymbol{d}$ та $\boldsymbol{e}$ відповідно.

За результатами підрахунку індексу «зеленої» економіки була побудована картосхема (рис. 1), що відображає територіальну відмінність у рівнях розвитку «зеленого» господарства. Найвище значення індексу зафіксоване у Херсонській області, що пояснюється значним розвитком альтернативної енергетики, незначними викидами забруднюючих речовин в атмосферу та великими площами об'єктів природно-заповідного фонду. Також варто зазначити, що для даної області характерний достатньо гармонійний розвиток всіх складових «зеленої» економіки. Схожим чином відбувається і розвиток «зеленого» господарства в Миколаївській області. Разом із вже вище зазначеними регіонами високе значення індексу має Хмельницька область через значний рівень вторинного використання ресурсів та відмінну забезпеченість природно-заповідним фондом.

Найнижчі значення індексу розвитку «зеленої» економіки мають високо урбанізовані та промислово розвинуті регіони країни: Київська, Харківська, Дніпропетровська та Донецька області.
Це спричинено, в першу чергу, високою часткою використання старих технологій у виробництві, що не відповідають сучасним вимогам енергоефективності. Високий рівень промислового виробництва, висока щільність розселення населення спричинюють низьку екологічних проблем у даних регіонах. I хоча в них також розвивається «зелене» господарство, темпи його зростання у індустріальних регіонах країни не відповідають потребам та можливостям даних областей.

Висновки і перспективи подалыших розвідок. 1. Запропоновано методичний підхід до оцінки регіональних відмінностей розвитку «зеленої» економіки в Україні на основі показників, що характеризують декілька секторів «зеленої» економіки: сфери переробки відходів, альтернативної енергетики та природно заповідної діяльності. Інтегральний коефіцієнт, що обрахований 3 урахуванням «вагових» коефіцієнтів, дозволяє говорити про існування міжрегіональних відмінностей у розвитку згаданих секторів. Херсонська та Миколаївська області мають найбільший поступ щодо розвитку альтернативної енергетики та невисоке техногенне навантаження на навколишнє середовище, що і обумовлює найвищі для них значення індексу. Найнижчі показники характерні для Київської, Харківської, Дніпропетровської та Донецької області. Це спричинено, в першу чергу, високою часткою використання старих технологій у виробництві, що не відповідають сучасним вимогам енергоефективності.

2. Запропонована методика може бути використана для оцінки поступу регіонів в напрямі «озеленення» економіки, що важливо 3 огляду на взяті Україною зобов'язання щодо реалізації цілей сталого розвитку. Для підвищення точності кінцевих результатів необхідно доповнити запропонований перелік показниками, що характеризують розвиток «зеленого» транспорту, будівництва, сільського господарства, туризму та інших секторів. Це вимагає вдосконалення системи збору статистичної інформації Державною службою статистики України та, можливо, здійснення щорічного обрахунку індексу розвитку «зеленої» економіки у регіонах подібно до регіонального людського розвитку.

\section{References:}

1. Burkins'kij B. V., Galuškìna T. P., Reutov V. Ê. «Zelena» ekonomika krìz' prizmu transformacìnih zrušen'v Ukraïì ["Green" economy throughout the prism of transformation changes in Ukraine]. Odessa-Saky, 2011,348 p. (In Ukrainian).

2. Čmir O. M., Zaharkevič N. P. Zelena ekonomìka: sutnìst', cìlì ta bazovì principi [Green economy: essence, goals and basic principles]. Ekonomičnij visnik Donbasu [Economic Bulletin of the Donbas], 2013, Vol. 3, pp. 54-62. (In Ukrainian).

3. Desât' umov perehodu do "Zelenoï Ekonomiki» [Ten requirements for the transition to "Green Economy"]. WBO (ICC). Document № 213-18/7 - 21 October 2011. (In Ukrainian).

4. Environvental Indicator Report 2013. EEA publication [Hanriette Nilson]. Copenhagen, 2013.

5. Green Economy. A guidance manual for the green economy indicators. UNEP, 2014.

6. Green Growth Best Practices: Syntehesis of Key Finding. Green Growth Best Practices. IGES, March 2014.

7. Hvesik M. A., Šubalìj O. M. Sučasna paradigma stalogo rozvitku v umovah globalizaciï» [Modern paradigm 
of the sustainable development under the conditions of globalization] Access mode: http://economics-of-nature.net/ uploads/arhiv/2011/Khvesyk.pdf (In Ukrainian).

8. Jacobs M. The Green Economy: Environment, Sustainable Development and the Politics of the Future. London: Pluto Press, 1991.

9. Kennet M., Heinemann V. Green Economics: setting the scene. Aims, context and philosophical underpinning of the distinctive new solutions offered by Green Economics. Int. J. Green Economics, 2006, Vol. 1.

10. Meadows D. H. The Limits to Growth; a report for the Club of the Rome's project on the predicament of mankind. New York, 1972.

11. Navstreču «zelënoj» èkonomike: puti k ustojčivomu razvitiûi iskoreneniû bednosti [Towards a Green Economy: Pathways to Sustainable Development and Poverty Eradication]. UNEP report, 2011. (In Russian).

12. Potapenko V. G. Strategičnì prìoriteti bezpečnogo rozvitku Ukraïni na naukovih zasadah «zelenoï ekonomiki» [Strategic priorities of the secure development of Ukraine based on the scientific ideas of the "green economy"]. Kyiv, 2012, 360 p. (In Ukrainian).

13. Statističnij ŝričnik Ukraïni za 2013 rik [Statistical Abstract of Ukraine 2013]. Kyiv, Office for National Statistics of Ukraine, 2014, 533 p. (In Ukrainian).

14. Statističnij zbirnik «Regioni Ukraïni» 2014 [Statistical Abstract "Regions of Ukraine" 2014]. Part 1, Kyiv, Office for National Statistics of Ukraine, 2014, 299 p. (In Ukrainian).

15. The Green City Index. A research project conducted by the Economist Intelligence Unit, sponsored by Siemens. Siemens AG, Munchen, Germany, 2012.

16. WWI. State of the World 2008: Innovations for a Sustainable Economy. New York, 2008.

17. Zakon Ukraïni «Pro osnovnì zasadi (strategîu) deržavnoï ekologǐčnoï politiki Ukraïni na perìod do 2020 roku» [Act of Ukraine "On the main guideline (strategy) of state ecology policy for the period until year 2020"]. Access mode: http://zakon2.rada.gov.ua/laws/show/2818-17. (In Ukrainian). 